DOI 10.18551/rjoas.2019-03.31

\title{
FACTORS AFFECTING PARTICIPATION OF FISHERMEN IN FISHERIES EXTENSION PROGRAM OF CILACAP COASTAL
}

\author{
Wiranto Bagus, Student \\ University of Diponegoro, Semarang, Indonesia
}

Bambang Azis Nur, Mudzakir Abdul Kohar, Lecturers

Faculty of Fisheries and Marine Sciences, University of Diponegoro, Semarang, Indonesia

\author{
*E-mail: bagusgo1331@gmail.com
}

\begin{abstract}
Information about the benefits and results of fisheries counseling on fishermen can be seen from the aspects of perceptions and participation of fishermen in participating in the fisheries extension program. This study aims to determine the factors that influence the participation of fishermen in fisheries extension programs viewed from the aspect of perceptions of the program itself and also the socio-economic characteristics of the fishermen. The method used is structural equation modeling (SEM) using the Amos 24 application. In this study 4 latent variables were used, namely fisherman characteristics, perceptions of fisheries instructor competencies, perceptions of fisheries extension services, and participation in fisheries counseling. The results of the study show that the factors that greatly influence participation in fisheries counseling are socio-economic characteristics including training, education, and organization, while in terms of perceptions of instructor competencies, the most important factor is the andragogic competence of the instructor itself. The variable perception of service shows that indicators of methods and techniques show the most dominant results. To increase the participation of fishermen in extension programs, training and socialization of the benefits of fisheries counseling need to be improved, besides that it is also necessary to encourage fishermen to join the fishing group. Whereas in terms of fisheries extension agents who carry out their duties, extension methods and techniques need to be improved with variations in extension materials and techniques. In addition, the involvement of fishermen in fisheries counseling (andragogic competencies) is expected to be able to increase patriarchy in fisheries counseling.
\end{abstract}

\section{KEY WORDS}

Perception, participation, fisheries extension, Structural Equation Modeling.

Cilacap Regency is one of the largest capture fisheries centers in Central Java Province. The administrative area of Cilacap Regency consists of 24 sub-districts. Cilacap Regency is also one of the districts in Central Java Province which is located on the southern coast of Java which has the highest number of fishermen compared to other districts in Central Java Province. The results of the Fisherman Card data collection in 2017 recorded more than 13,000 active fishermen conducting fishing businesses in this district.

The management of capture fisheries development in almost all regions of Indonesia cannot be separated from the management and development of fishermen's human resources as the main actors and business actors in this subsector. One approach to developing fishermen's human resources is through fisheries extension activities. This is in accordance with the strategic plan of the Ministry of Maritime Affairs and Fisheries for 20152019. According to Sumardjo (2008) the main focus of extension is human development as part of the social system. Extension attempts to construct community structures in a convergent, dialogical, democratic and participatory manner.

Information about the benefits and results of fisheries extension programs can be seen in terms of perceptions and participation of fishermen as beneficiaries of fisheries extension services, so that it can be seen how the fishermen receive fisheries extension programs that 
have been implemented. Chaigneau (2016) shows that people's perceptions are influenced by one's views on a situation, fact or action. Therefore individuals need to clearly understand the goals and responsibilities given to them. One of the basic factors of perception is the ability of people to gather limited facts and parts of information and then arrange in a complete description.

Sofia's results (2015) showed that fishermen's perceptions of the instructor's competence were able to increase fishermen's participation in extension. Where this indicates that a fisherman will feel comfortable when the instructor can explain the extension program easily and interestingly. The results of the Arlinghaus et al. (2015) study show that the perception of fishermen on extension services is able to increase the participation of fishermen in extension. Where this indicates that a fisherman will feel comfortable participating in extension when the extension provides good service to fishermen.

Based on the description above, knowledge of the factors that influence fishermen's participation in extension programs is needed so that fisheries extension, especially for fishermen in coastal areas, can be effective and efficient. Therefore this study aims to determine the factors that influence fisherman participation seen from the aspect of extension services and the competence of fisheries educators, especially in the coastal areas of Cilacap Regency.

\section{MATERIALS AND METHODS OF RESEARCH}

This research was conducted in Cilacap Regency as one of the capture fisheries centers in Java and also in Central Java Province. The research area is specifically in nine sub-districts that have coastal areas so that it can be ascertained that these sub-districts are fishing centers. The nine sub-districts are Patimuan, Kampung Laut, South Cilacap, Central Cilacap, North Cilacap, Kesugihan, Adipala, Binangun, and Nusawungu. This Research is conducted from December 2018 to January 2019.

The study population was all small fishermen with vessels less than 10 GT in Cilacap Regency. The population of fishermen is 12,719 people (2017 Cilacap Statistic Board). The method used is the survey method with the number of samples taken as many as 180 respondents selected purposively from fishermen who had attended extension activities along the coast of Cilacap Regency.

Table 1 - Fisherman Population and Number of Samples Taken

\begin{tabular}{|c|c|c|c|}
\hline No & Sub DIstrict & Fishermen Population (2016) & Amount Of Sample \\
\hline 1 & Patimuan & 389 & 10 \\
\hline 2 & Kampung laut & 1461 & 20 \\
\hline 3 & Cilacap tengah & 1589 & 20 \\
\hline 4 & Cilacap selatan & 4674 & 55 \\
\hline 5 & Cilacap utara & 2298 & 30 \\
\hline 6 & Kesugihan & 696 & 10 \\
\hline 7 & Adipala & 584 & 10 \\
\hline 8 & Binangun & 72 & 10 \\
\hline 9 & Nusawungu & 956 & 15 \\
\hline & Total & 12.719 & 180 \\
\hline
\end{tabular}

Source: 2017 Cilacap District Statistic Book.

To find out the factors that influence the level of participation of fishermen in the coastal area of Cilacap in fisheries extension, the research carried out was a type of survey research using a questionnaire to obtain the required data from respondents. The method used is a non-experimental design method, because all data to be taken has been available in the field and indeed no control over the overall variables used.

The data analysis used in this study is the Structural Equation Modeling (SEM) model, used to determine the factors that influence fishermen's participation in fisheries extension programs. the stages in SEM analysis in this study include the study of the theory, specification of the model, estimation, hypothesis testing, and interpretation of the model. 
In studying a person's perception or group, knowledge is needed about the characteristics of a person or group. Nababan (2017) states that the socio-economic characteristics of fishermen can influence the perception of fishermen. The socio-economic characteristics in question are age, education, experience, organizational experience, training experience, scale of business and dependents. Therefore in this study socioeconomic characteristics can be used as exogenous variables (X).

Furthermore, in determining the endogenous variables that will be included in the model in fisheries extension programs that are programs related to the field of service to the community, of course the most influential thing is the ability of extension agents to carry out extension and extension services themselves. Therefore the first endogenous latent variables included in the model are perceptions of instructor competencies (Y1) that relate to the ability of fisheries instructors in conducting fisheries extension activities. Based on the SKKNI (National Work and Competence Standard)of fisheries extension that the instructor's competence consists of personality, andragogic, professional, and social competencies (Farida, 2012; Haryadi, 2014; Zulfikar, 2017).

Table 2 - Latent variables and indicator in model

\begin{tabular}{|c|c|c|}
\hline Latent Variable & Indicator & Description \\
\hline $\begin{array}{l}\text { Socio-economic } \\
\text { characteristics }(X)\end{array}$ & 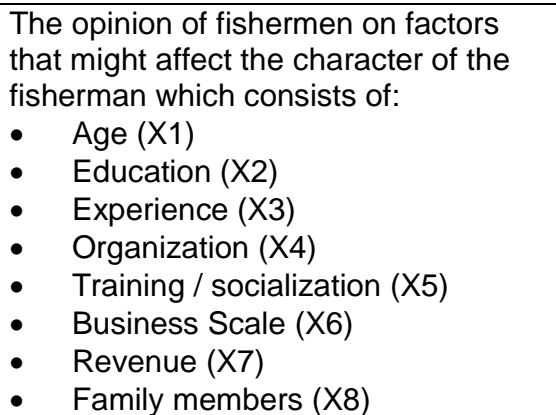 & $\begin{array}{l}\text { It is a question of whether these characteristic } \\
\text { factors affect the character of the fisherman. } \\
\text { Data in the form of scale like likert with values } \\
\text { (1) strongly disagree, (2) disagree, (3) doubt, } \\
\text { (4) agree, (5) strongly agree }\end{array}$ \\
\hline $\begin{array}{l}\text { Perception of } \\
\text { Competence of } \\
\text { Fisheries Extension } \\
\text { officer (Y1) }\end{array}$ & $\begin{array}{ll}\text { - } & \text { Perception of Individual } \\
& \text { competence (Y11) } \\
\text { - } & \text { Perception of Competence (Y12) } \\
\text { - } & \text { Perception of Professional } \\
& \text { Competence (Y13) } \\
\text { - } & \text { Perception of Social Competence } \\
& (\mathrm{Y} 14)\end{array}$ & $\begin{array}{l}\text { Based on the Minister of Manpower and } \\
\text { Transmigration Regulation No. } 403 \text { of } 2014 \\
\text { concerning SKKNI Fisheries Extension, which } \\
\text { was translated according to Sumardjo (2009). } \\
\text { Data In the form of like likert scale data about } \\
\text { questions related to Perception about } \\
\text { Competency extension officers then tabulated } \\
\text { and ranked according to scale: } \\
\text { (1) Very low } \\
\text { (2) Low } \\
\text { (3) Moderate } \\
\text { (4) High } \\
\text { (5) Very High }\end{array}$ \\
\hline $\begin{array}{l}\text { Perception of } \\
\text { extension services } \\
\text { (Y2) }\end{array}$ & $\begin{array}{ll}- & \text { Extension Intensity (Y21) } \\
\text { - } & \text { Extension material (Y22) } \\
\text { - } & \text { Methods and Extension } \\
& \text { Techniques (Y23) }\end{array}$ & $\begin{array}{l}\text { Data in the form of like likert scale data about } \\
\text { questions related to Perception about } \\
\text { Fisheries extension services then tabulated } \\
\text { and ranked according to scale: } \\
\text { (1) Very low } \\
\text { (2) Low } \\
\text { (3) Moderate } \\
\text { (4) High } \\
\text { (5) Very High }\end{array}$ \\
\hline $\begin{array}{l}\text { Fisherman } \\
\text { Participation in } \\
\text { Extension Program } \\
\text { (Y3) }\end{array}$ & $\begin{array}{ll}- & \text { Extension planning (Y31) } \\
\text { - } & \text { Implementation of extension (Y32) } \\
\text { - } & \text { Enjoy the results of extension } \\
& \text { (Y33) } \\
\text { - } & \text { Evaluation of the extension } \\
\text { program (Y34) }\end{array}$ & $\begin{array}{l}\text { Data in the form of data like Likert scale } \\
\text { about questions related to fisherman } \\
\text { participation in Extension Programs and then } \\
\text { tabulated and ranked according to scale: } \\
\text { (1) Very low } \\
\text { (2) Low } \\
\text { (3) Moderate } \\
\text { (4) High } \\
\text { (5) Very High }\end{array}$ \\
\hline
\end{tabular}

Source: Nababan (2017), Zulfikar (2017), Haryadi (2014), Farida (2012). 
Then the second endogenous latent variable is the perception of extension services (Y2) which is the interpretation of fisheries extension activities itself which consists of the intensity of extension, methods, materials and extension techniques. Fisheries extension program is a program that has the nature of direct service to the community so that the extension agent as a subject and extension service plays an important role in the formation of perceptions (Farida, 2012; Haryadi, 2014; Zulfikar, 2017).

The next endogenous latent variable is participation in an extension program that is determined by evaluating participation in each stage of extension starting from planning, implementing, enjoying the program or the results and evaluation. Saptorini (2003), Ayunita and Hapsari (2012), Nababan (2017) states that good public perceptions will encourage high community participation. Besides perceptions, the socio-economic characteristics of fishermen are also used as variables that influence participation (Saptorini, 2003; Yuwono 2006; Nababan 2017).

The exogenous latent variable used consisted of fishermen's opinion on the factors that might influence the character of the fisherman consisting of age, education, experience, organization, training, business scale, income, dependents. While the endogenous latent variables used were three, namely perceptions of the ability of extension agents to carry out extension consisting of perceptions of instructor competencies with the observed variables including perceptions of the individual, andragogical, professional and social aspects of the existing fisheries instructors. and perceptions of extension services with the observed variables are intensity, material and methods of extension. Besides the last endogenous variable is the participation of fishermen in participating in fisheries extension with the observed variables being participation in planning, implementing, enjoying the results, and evaluating fisheries extension.

In this study using the Maximum Likelihood Estimator (MLE) estimator. For research with a moderate number of indicators and a limited scope of areas, many researchers use this model estimator. Goodness of Fit examination is carried out at the next stage or after the estimation is made. Respecification by utilizing information on Modification Indices (MI) through AMOS 24 software and carried out if the feasibility measure of a model does not meet (Haryono \& Wardoyo, 2012). Hypothesis testing is done to test whether the regression coefficient obtained is significant at the $95 \%$ confidence interval.

\section{RESULTS AND DISCUSSION}

Structural equation models of the factors that influence fishermen's participation in fisheries extension programs are seen from the characteristics and perceptions of extension programs can be seen from Figure 1. Models that have been formed and estimated are then interpreted to obtain information that is useful for the development of fisheries extension programs specifically to small fisherman.

A good model is a model that has Goodness of Fit (GOF) that meets the criteria. In this study the size of Goodness Of Fit (GOF) can be seen in table 3. It can also be seen in outline the value of Goodness Of Fit (GOF) in the estimated model at the marginal fit index, which is between 0.80-0.90, so it can be concluded that the estimated model is good with a good level of compatibility too.

The coefficient of determination $\left(R^{2}\right)$ is indicated by the value of Squared Multiple Correlations. The magnitude of the coefficient of determination for the Participation variable (Y3) is 0.322 . Meaning that the participation variable has been explained by $32.2 \%$ by the variables contained in the model, and the remaining $67.8 \%$ participation of fishermen is influenced by other factors.

There are two influences that exist between the latent variables that are interconnected, namely direct or indirect influences. While the direct influence on the model is six direct influences which are translated into six hypotheses, namely:

Hypothesis 1:

$\mathrm{H}_{0}$ : Individual characteristics have no effect on perceptions of instructor competency;

$\mathrm{H}_{1}$ : Individual characteristics influence the perception of the instructor's competence. 
Hypothesis 2:

$\mathrm{H}_{0}$ : Individual characteristics do not affect the perception of extension services;

$\mathrm{H}_{1}$ : Individual characteristics influence the perception of extension services.

Hypothesis 3:

$\mathrm{H}_{0}$ : Individual characteristics do not affect participation in extension;

$\mathrm{H}_{1}$ : Characteristics of individuals influence participation in extension.

Hypothesis 4:

$\mathrm{H}_{0}$ : Perceptions of extension services have no effect on perceptions of the competence of extension agents;

$\mathrm{H}_{1}$ : Perception of extension services has an effect on perceptions of the competence of extension agents.

Hypothesis 5:

$\mathrm{H}_{0}$ : Perception of the instructor's competence does not affect participation in extension;

$\mathrm{H}_{1}$ : Perception of counselor's competency influences participation in extension.

Hypothesis 6:

$\mathrm{H}_{0}$ : Perception of extension services does not affect participation in extension;

$\mathrm{H}_{1}$ : Perception of extension services influences participation in extension.

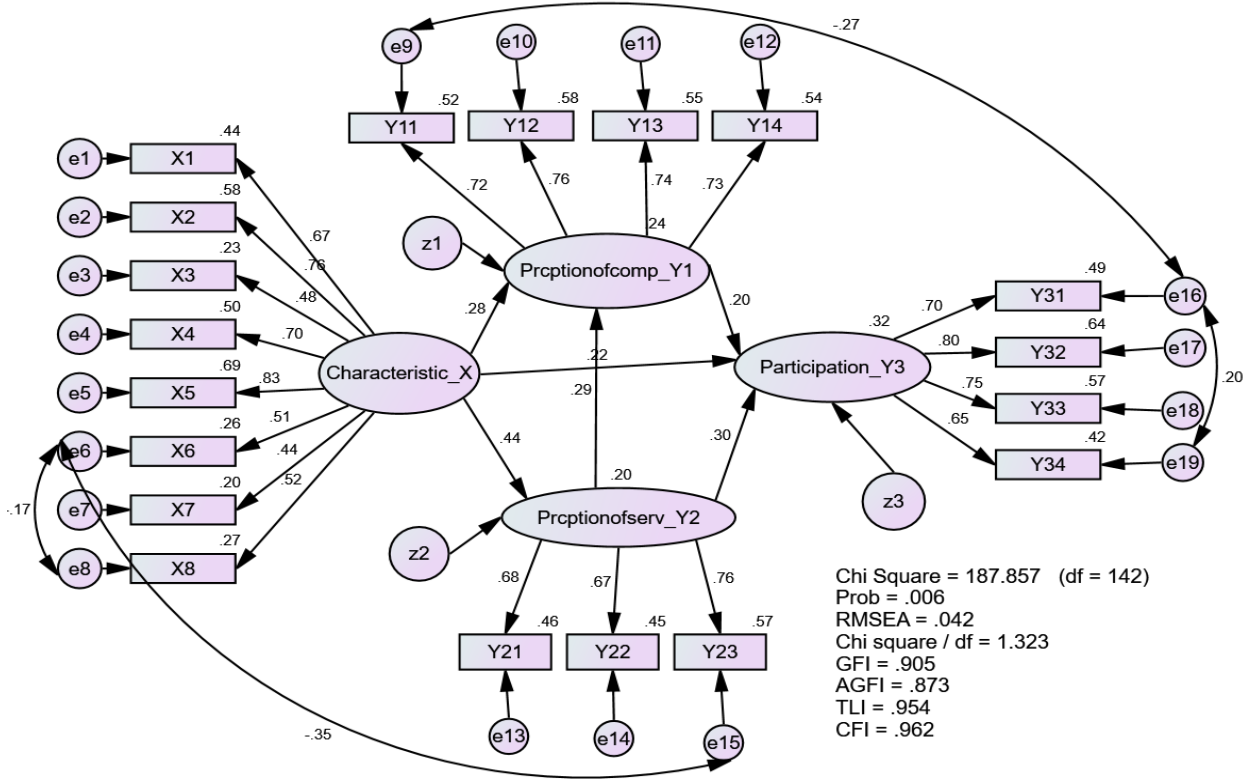

Figure 1 - Structural equation model of the factor that affecting fishermen participation in fisheries extension program

Table 3 - Model Goodness of Fit (GOF)

\begin{tabular}{|c|c|c|c|c|}
\hline No & Match size & Model Fit Terms & Result & Model Evaluation \\
\hline 1 & Chi Square & Expected lower & 187.857 & Good \\
\hline 2 & Probability & $>0.05$ & 0.006 & Not Good \\
\hline 3 & Root Mean Square eror (RMSEA) & $\leq 0.8$ & 0.042 & Good \\
\hline 4 & CMIN/df & $<5$ & 1.323 & Good \\
\hline 5 & GFI & $\geq 0.9$ & 0.905 & Good \\
\hline 6 & AGFI & $\geq 0.9$ & 0.873 & Moderate \\
\hline 7 & TLI & $\geq 0.9$ & 0.954 & Good \\
\hline 8 & CFI & $\geq 0.9$ & 0.962 & Good \\
\hline
\end{tabular}

Source: Data Processing Result, 2019.

In seeing which decisions will be taken, it can be seen from the probability value ( $p$ value), if the value ( $p$-value) is equal to or smaller than 0.05 then $\mathrm{H}_{0}$ is rejected and $\mathrm{H}_{1}$ is accepted. Furthermore, the results of the regression coefficients and the results of 
hypothesis testing on the direct influence between existing latent variables can be seen in Table 4.

Table 4 - Direct effect between each latent variable

\begin{tabular}{|c|c|c|c|c|c|c|}
\hline Regression & Coefficient & Standardized Coefficient & t-stat & p-value & Hypothesis & Decision \\
\hline Y1<---X & 0.384 & 0.284 & 2.746 & 0.006 & Hypothesis 1 & $H_{1}$ Accepted \\
\hline Y2<---X & 0.757 & 0.444 & 4.133 & 0.000 & Hypothesis 2 & $H_{1}$ Accepted \\
\hline Y3<---X & 0.312 & 0.222 & 2.183 & 0.029 & Hypothesis 3 & $\mathrm{H}_{1}$ Accepted \\
\hline Y1<---Y2 & 0.230 & 0.290 & 2.749 & 0.006 & Hypothesis 4 & $\mathrm{H}_{1}$ Accepted \\
\hline Y3<-- Y1 & 0.205 & 0.197 & 2.002 & 0.045 & Hypothesis 5 & $\mathrm{H}_{1}$ Accepted \\
\hline Y3<-- Y2 & 0.247 & 0.299 & 2.741 & 0.006 & Hypothesis 6 & $\mathrm{H}_{1}$ Accepted \\
\hline
\end{tabular}

Source: Data Processing Result, 2019.

Table 4 shows that all direct effects produce a smaller or equal $p$-value of 0.05 so that the decision taken is to accept all $\mathrm{H}_{1}$, the most significant thing is that fishermen's characteristics influence the perception of extension services with a $p$-value of 0.000 . While the lowest is the perception of extension competencies affecting participation in fisheries extension with a p-value of 0.045 . From the elaboration of the results of the above model tests it can be seen that the characteristics and perceptions of competency and fisheries extension services affect the participation of small fishermen in fisheries extension.

While the existing latent variables also have an indirect influence on other variables through intervening variables. The value in table 5 can show direct effect, indirect influence and total influence between existing latent variables.

Table 5 - Direct, indirect, and total effect between latent variable

\begin{tabular}{|c|c|c|c|}
\hline Regression & Direct effects & Indirect effects & Total effects \\
\hline Y3<--- X & 0.222 & 0.214 & 0.436 \\
\hline Y3<---Y1 & 0.197 & 0.000 & 0.197 \\
\hline Y3<--Y $Y 2$ & 0.299 & 0.057 & 0.356 \\
\hline
\end{tabular}

Source: Data Processing Result, 2019.

In Table 5, it can be seen that the value of the indirect effect between the characteristics of fishermen $(X)$ and participation $(Y 3)$ is 0.214 . This value is the value of the magnitude of the influence of fisherman characteristics $(X)$ on participation $(Y 3)$ through the perception variable on the instructor's competency $(\mathrm{Y} 1)$ and through the perception variable on fisheries extension services (Y2). The value of the indirect effect and the direct effect value are almost the same, were 0.222 and 0.214 . This value can be explained that the two variables were perceptions of instructor competency (Y1) and perceptions of extension services (Y2) are intervening variables that influence fishermen's participation in fisheries extension.

Table 5 also shows the value of the total effect of independent latent variables (X, Y1, $Y 2)$ on the dependent latent variable (Y3). The biggest total influence is the influence of fisherman characteristics $(X)$ on participation (Y3), the existing value shows an indirect effect of 0.436 so that it can be explained that the fisherman's character and the instructor's ability to increase fisherman participation are equally influential and have an effect of 0.436 . While the perception of services and perceptions of the competency of fisheries instructors provide an influence value of 0.356 . This shows that the perception of extension services is far more influential in increasing fishermen's participation in fisheries extension program.

In addition to some of the relationships above, other relationships that can be analyzed from the model are relationships between latent variables and their manifest variables (indicators of each variable). The value of the relationship that occurs is indicated by the value of the load factor (loading factor) of each indicator. The highest value of each of these indicators is the indicator that has the most or most dominant role in explaining its latent variables. The loading factor value can be seen in Table 6 . 
Table 6 - Factor loading of each latent variable

\begin{tabular}{|c|c|c|c|c|c|}
\hline Manifest & Factor loading & Standardized Factor loading & \multirow{2}{*}{-stat } & p-value & \multirow{2}{*}{ Explanation } \\
\hline KAR1(X1) & 1.203 & 0.665 & 6.232 & 0.000 & Significant \\
\hline KAR2 $(\mathrm{X} 2)$ & 1.754 & 0.760 & 6.673 & 0.000 & Significant \\
\hline KAR3(X3) & 0.941 & 0.484 & 5.097 & 0.000 & Significant \\
\hline KAR4(X4) & 1.583 & 0.705 & 6.427 & 0.000 & Significant \\
\hline KAR5(X5) & 1.878 & 0.831 & 6.932 & 0.000 & Significant \\
\hline KAR6(X6) & 0.691 & 0.507 & 4.910 & 0.000 & Significant \\
\hline KAR7(X7) & 0.695 & 0.445 & 4.796 & 0.000 & Significant \\
\hline KAR8(X8) & 1.000 & 0.522 & - & 0.000 & Significant \\
\hline PERPri(Y11) & 1.000 & 0.719 & - & 0.000 & Significant \\
\hline PERAndra(Y12) & 0.966 & 0.763 & 9.017 & 0.000 & Significant \\
\hline PERProf(Y13) & 0.956 & 0.741 & 8.810 & 0.000 & Significant \\
\hline PERSos(Y14) & 0.967 & 0.734 & 8.738 & 0.000 & Significant \\
\hline PERInt(Y21) & 0.767 & 0.679 & - & 0.000 & Significant \\
\hline PERMat(Y22) & 0.911 & 0.668 & 7.297 & 0.000 & Significant \\
\hline PERMet(Y23) & 1.000 & 0.755 & 7.230 & 0.000 & Significant \\
\hline PARRen(Y31) & 1.000 & 0.697 & - & 0.000 & Significant \\
\hline PARLak(Y32) & 1.119 & 0.800 & 8.615 & 0.000 & Significant \\
\hline PARHas(Y33) & 1.025 & 0.752 & 8.380 & 0.000 & Significant \\
\hline PAREv(Y34) & 0.913 & 0.647 & 8.509 & 0.000 & Significant \\
\hline
\end{tabular}

Source: Data Processing Result, 2019.

Table 6 shows that of the eight exogenous indicators all variables showed significant values, the values of the eight variables were training and outreach indicators (X5) and education indicators (X2) which showed the most dominant value in explaining the latent variables.

While the endogenous variables ( $\mathrm{Y} 1, \mathrm{Y} 2$, and $\mathrm{Y} 3$ ) also show significant values. The most dominant indicator of the perception variable on fisheries extension instructor competencies (Y1) is Andragogic Competence (Y12). The most dominant indicator of the perception variable on extension services (Y2) is the perception of extension methods and techniques (Y23). Furthermore, the most dominant indicator of the variable participation of fishermen in fisheries extension (Y3) is participation in the implementation of fisheries extension.

\section{DISCUSSION OF RESULTS}

Based on the results of research and data processing in the AMOS 24 application at a $95 \%$ confidence level (alpha-0.05), the socio-economic characteristics of fishermen were able to influence the participation of fishermen in fisheries extension programs. The influence of the socio-economic characteristics of fishermen is able to provide an influence value of 0.22 . This shows that the higher the level of social economic characteristics of fishermen, the more their participation in extension programs, but the characteristics are not the only factors that contribute to the participation of fishermen in extension programs.

The indicators found in the latent variables of the socio-economic characteristics of the most contributing fishermen are training/socialization, education and organization. These results indicate that the indicators that most play a role in the formation of variable characteristics of fishermen especially encourage fishermen to participate in fisheries extension programs. The results also meant that fishermen who had attended training and outreach tended to participate more than other fishermen in fisheries extension. Therefore, the need for appropriate training and socialization and also the intensification of training and outreach to fishermen needs to be added. Training and outreach to fishermen is a concrete form of support from the government and policy makers in the field of marine and fisheries towards the existence of small fishermen. Mardijono (2008) states that a comprehensive and sustainable socialization is needed for the community regarding government programs. 
In addition, based on the results of the existing model, education and organizational experience also have an influence in encouraging fishermen to participate in fisheries extension. The need to develop fishing organizations is also a real step in improving fishermen's institutions which will lead towards fishermen who have more insight into business management. The growth program and development of existing fishermen groups should continue to be considered and improved by fisheries extension workers, so that new groups will be formed and existing groups will develop their business management. Education is also one indicator that plays a role in forming the characteristics of fishermen. This can be considered also to make fishermen who have higher education than surrounding fishermen to be able to run group management so that other fishermen around them can benefit from extension. This has been applied to the fishermen of Rawajarit, Subdistrict Kesugihan Village who appoint a fisherman with a higher level of education to manage the group as well as the cooperatives that are run.

Fishermen's perception of the competency of fisheries instructors also significantly influences their participation in fisheries extension programs. The results of the calculation of the existing model show a positive value which means that fishermen who assess the competency of fisheries instructors with higher scores tend to have better participation. The indicators that have the most role in increasing fishermen's participation through their perceptions of the competency of fisheries instructors are the andragogic competencies of fisheries instructors. Haryadi (2014) explains that Andragogic Competence of fisheries extension agents is the ability of fisheries instructors to understand and develop learning needs to change. The meaning is how the ability of the fisheries extension agent to better involve fishermen in the structure of the fisheries extension process.

According to Haryadi (2014) that fisheries extension agents in Cirebon Regency also need to improve their competencies so that the perceptions of farmers to extension programs are higher. Baba (2011) also stated that perceptions of cattle farmers in Enrekang District on extension had a positive effect on the level of participation in extension, the better their perceptions of extension, the higher the level of participation. The functional ability factor of the instructor itself also greatly influences the level of participation of farmers in Enrekang Regency in participating in Extension. Therefore, it can also be concluded that the instructor's competencies need to be improved so that fishermen's participation in fisheries extension activities can also be maximized.

In addition to fishermen's perceptions of the competence of extension agents, data on fishermen's perceptions of extension services were also successfully collected and summarized. The results show that fishermen's participation in extension also depends on how the fisherman extension services itself. Existing values indicate that services have a greater role than fishermen's perceptions of their extension competencies. This happens because the approach to fishermen is a bit more difficult than the approach to other business actors such as processors and farmers. Time limitations and low levels of education are the main factors in conducting extension services to fishermen. However, when fishermen feel comfortable with the extension, extension activities will be a little easier to do.

Extension workers in Cilacap Regency are also still very limited so that to serve a large number of fishermen along the coast of Cilacap, there are also a few obstacles. This can be seen from the indicators of extension intensity which are considered lower than other indicators in Perception of extension services. But in terms of methods and techniques of extension in Cilacap District in general it has been very mastering, as well as in terms of extension materials which are considered to be quite good. This is also caused by the extension workers at many expert and senior levels being placed in fishing center subdistricts in Cilacap Regency.

The participation variable shows that indicators of the implementation of fisheries extension are still the most dominant indicator in fishermen's participation in fisheries extension. This shows that the participation of Cilacap District fishermen in fisheries extension is still limited to the implementation stage and enjoying the results, but in terms of fisheries extension planning and evaluation of fisheries extension is still lacking. In the fisheries patrisipation planning stage, it is still limited to fishermen who are generally elder 
and administrators of the fishermen group itself. Besides that, the awareness of fishermen to assist in the planning stage such as collecting initial data is also very low, as well as during fisheries extension evaluations. Community participation in community forest development in partnership patterns is also low at the planning and evaluation stage because at that stage the opportunity to participate is given to certain communities, namely leaders or community leaders (Yuwono, 2006). Mardijono (2008) also concluded that fishermen's participation in the management of the Batam City Marine Protected Area was also very good at implementation but slightly reduced at other stages, especially monitoring and evaluation.

\section{CONCLUSION}

The socio-economic characteristics that most play a role in increasing participation in extension are training and outreach, education and organization, while the perception of the competency of fisheries instructors who plays the most important role is the perception of andragogic competencies of fisheries instructors.

\section{ACKNOWLEDGEMENTS}

The results of this study are part of the results of the author thesis research. A big thank you goes to the Head of the Marine and Fisheries Extension and Training Center and the Head of the Center for Marine and Fisheries Education of the Marine and Fisheries Human Resources Research Agency and all staff for the opportunity to continue the studies and assistance both morally and materially. In addition, authors also thank the Cilacap District Fisheries Service and all Cilacap District extension officers who have assisted in collecting data in the field.

\section{REFERENCES}

1. Arlinghaus B; R Tillner; and M Bork, 2015, Explaining participation rates in recreational fishing across industrialised countries, Fisheries Management and Ecology, 2015, 22, 45-55.

2. Ayunita, Dian and Hapsari, Trisnani, 2012, Analisis Persepsi and Partisipasi Masyarakat Pesisir pada Pengelolaan KKLD Ujungnegoro, Kabupaten Batang. Jurnal Sosial Ekonomi Pertanian and Agribisnis 9(1):117-124. UNDIP Semarang.

3. Baba, S., Isbandi., T Mardikanto. 2011. Faktor-Faktor Yang Mempengaruhi Tingkat Partisipasi Peternak Sapi Dalam Penyuluhan Di Kabupaten Enrekang. JITP Vol. 1 No.3, Juli 2011.

4. BPS Kabupaten Cilacap. 2017. Cilacap Dalam Angka Tahun 2017.

5. Chaigneau, T. 2016. Compairing The Perception of fisherman Towards MPAs and The Status of their Adjacent Coral Reefs Between Coastal Communities in the Filiphines. Journal Of Animal Ecology.

6. Ditton, Robert B; Thomas J. Mertens, and Martin P. Schwartz, 2017. Characteristics, Participation, and Motivations of Texas Charter Boat Fishermen. MFR Paper.

7. Farida. 2012. Persepsi Petani Terhadap Kompetensi Penyuluh Pertanian lapangan Di Kecamatan Pontang, Kabupaten Serang, Provinsi Banten. TESIS Sekolah Pascasarjana IPB. Bogor.

8. Haryadi, Ikhsan. 2014. Persepsi Pembudidaya Ikan Terhadap Kompetensi Penyuluh Perikanan di Kawasan Minapolitan Kabupaten Cirebon Provinsi Jawa Barat. TESIS Sekolah pascasarjana IPB. Bogor.

9. Haryono, S., \& Wardoyo, P. 2012. Structural equation modelling: untuk penelitian menggunakan Amos 18 (p.333). Bekasi: PT. Intermedia PersonalUtama.

10. Kementerian Tenaga Kerja and Transmigrasi 2014. KEPMEN 403/MEN/VIII 2014 Penetapan Standar Kompetensi Kerja Nasional Indonesia Sektor Kelautan and Perikanan Bidang Penyuluhan Perikanan. 
11. Mardijono. 2008. Persepsi and Partisipasi Nelayan Terhadap pengelolaan Kawasan Konservasi laut Kota Batam. TESIS. Program Pascasarjana MSDP UNDIP. Semarang.

12. Nababan, Bernando. 2017. Persepsi and Kepatuhan Nelayan Tanjung Balai Asahan Sumatera Utara Dalam Mendukung Perikanan Tangkap Yang Berkelanjutan. TESIS. Sekolah Pascasarjana. IPB. Bogor.

13. Panagopulou, Aliki; Zoe A Meletis; Dimitris Margaritoulis; and James R Spotila, 2017, Caught in the Same Net? Small-Scale Fishermen's Perceptions of Fisheries Interactions with Sea Turtles and Other Protected Species, Original Research.

14. Saptorini, 2003. Persepsi and Partisipasi Masyarakat Dalam Pelaksanaan Konservasi Hutan Mangroove Di Kecamatan Sayung Kabupaten Demak. TESIS Program Pascasarjana UNDIP. Semarang.

15. Silviyanti, Serly, Amirudin Saleh, Musa Hubeis, and Ninuk Purnaningsih, 2015. Fishermen's Characteristic Profile in Using of the Media Communication in Pasaran Island, Bandar Lampung City. International Journal of Humanities and Social Science.

16. Sofia, Leila A. 2015. Fishermen's perception and participation in fisheries resources conservation of Batungaps wamp in Tapin Regency, South Kalimantan, Indonesia, AACL Bioflux, 2017, Volume 10, Issue 6.

17. Yuwono, Setyo. 2006. Persepsi and Partisipasi Masyarakat Terhadap Pembangunan Hutan Rakyat Pola Kemitraan di Kabupaten Musi Rawas Propinsi Sumatera Selatan. TESIS Pascasarjana IPB. Bogor.

18. Zulfikar. 2017. Persepsi Petani Terhadap Kompetensi Penyuluh Tanaman Pangan di Kabupaten Aceh Utara. TESIS Pascasarjana IPB. Bogor. 